\title{
Research on the seasonal change of lip surface condition
}

\author{
Minoru Maruyama, Masatugu Sugamuma, Chieko Tuchiya \\ Junji Shiozawa and Keiichi Nishimura
}

\begin{abstract}
Lip has a characteristic skin compared with other part of skin. The studies on lip skin are quite a few. To investigate the seasonal change of lip condition, same evaluation methods were applied, such as analyzing photographs of lips, measuring moisture content with impedance meter, measuring color with color and color difference meter and taking surface temperature.

These evaluation methods were applied to 35 women (the average age is 32.8 years old ranging from twenties to fifties), and executed six times in a year; september, November, January, April and June. As the results, the followings are proven: lip becomes chapped not only in the winter time but in around June, and its moisture content certainly decreases in the winter time. The younger women's lips get chapped more easily. The group of a high moisture content and low transepidermal water loss (TWL) is significantly less chappy. The group of a lower surface temperature than average is significantly chappy,
\end{abstract}

\section{1. 緒 言}

口唇は口腔粘膜から皮膚にいたる移行帯をなして拉 り，皮脂の分泌が少なく，汗腺も極めて少ない。また， 角質化の弱い上皮に覆われているため透明度が高く, 表 皮下に浅く密に分布する毛細血管により肌とは異なった 色調を有する等の特徵がある。

肌の季節変化については, 多くの研究が行なわれてき ているが，口唇そのものの研究報告1),2は汪とんどみら れない。

そこで，荒れやすくデリケートな部位で，特に冬には 皮むけやひび割れし荒れやすいといわれている唇の季節 変化を把握する目的で，いくつかの評価法を試みた。そ の結果, 口唇の荒れや表皮水分量等の季節変化について 知見を得たので報告する。

\section{2. 実 験}

\section{1 測定日時, 環境条件, 被験者}

口唇の季節変化をみるため, 以下の 6 回を測定時期之

ポーラ化成工業侏静岡研究所: 静岡市弥生町 648

R \& D Laboratories POLA Corporation.; 648 Yayoi-cho, Shizuoka

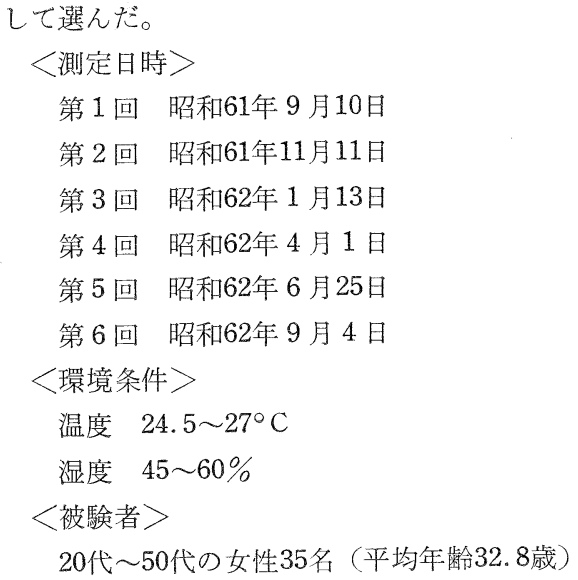

\section{2 測定方法}

口紅類をクレンジングクリームと拭きとり化粧水で落 とし，20分後に測定を開始した。測定中は唇をなめたり 手でさわったりしないよう，被験者に協力していただい た。

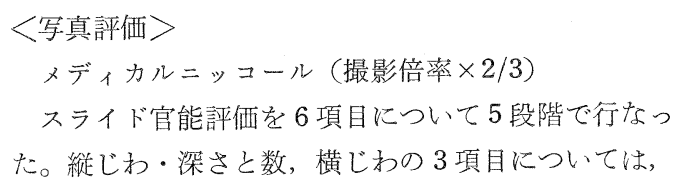


第 1 回を基準として，他の時点との相対評価をした。 荒れ：1 (荒れていない) ～5（すごく荒れている） ささくれ：1（無い）～5（多い）

乾いた感じで皮もけ，ひび割れしささくれている状 態の程度を評価した。（Fig.-1 は，ささくれ2.8であ った )

かいよ5：1（無い）～5（多い）

外観で観察できる炎症，ただれの状態の程度を評価 した。(Fig.-2 は，かいよら2.4であった。)

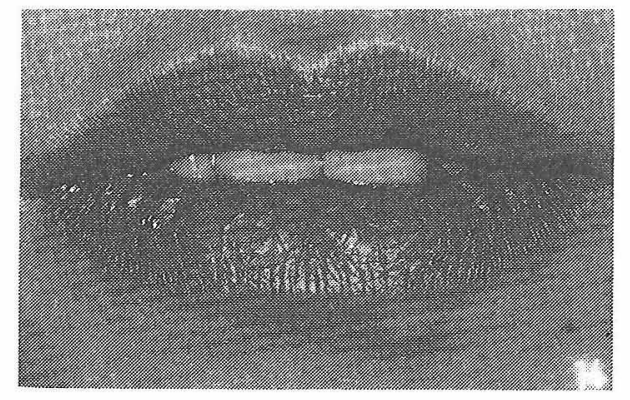

Fig.-1 Typical photograph of a hangnail on lip condition

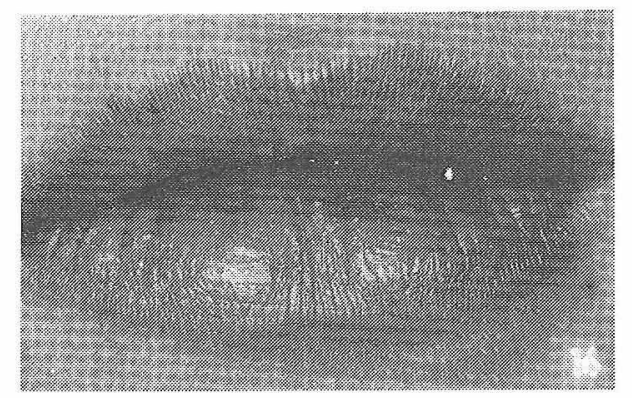

Fig.-2 Typical photograph of an ulcer on lip condition

〈測色〉

ミノルタ色彩色差計 CR-100データプロセッサ DP100 付属
唇に接触する部分は，サランラップでマスクし，5 ケ所の測定からの平均俻を求めた。下唇を中心に，参 考として上唇も測定した。

〈インピーダンス>

IBS SKICON-100 PROBE SSH-8

インピーダンスによる表皮水分量測定は，唇をその 屯忠状熊（IP1）とのばした状態 (IP2)で，下唇中 心部を各々 3 回測定し得られたコンダクタンスの平均 值を用いた。

〈表面温度〉

GRANT スクライルメータ ロガー センサー FF 上・下唇の中心及び左不各々 3 ケ所の測定を行ない その平均値を用いた。

〈自己診〉

測定時の口唇の荒れ状態と，年間を通しての口唇の 荒れやすさについて，3段階評価で自己申告してもら つた。

参考に测定した項目として

<体温〉

テルモ電子体温計 ET-C21P

$\langle\mathrm{TWL}\rangle$

SERVO MED エバポリメーターEP-1

口唇全体にセンサー部をあて，20秒間呼吸を止めた 状態で TWL 值をレコーダーにて記録し平均值を得 た。

\section{3. 結果と考察}

测定結果の有意差については $\mathrm{t}$ - 検定, 相関係数の検 定はr表によって行なった。

\section{1 荒れ評価点の柰節変化と年龄羑}

Table-1に示されるよらに，荒れ評洒点は11月，1月 と冬になるにつれて，増加傾向にあり唇の荒れが進んだ ことがわかる。4月になって回復傾向が文られるか， 6 月になって再び荒れが戻る現象がみられた。これは夏に なり、リップクリーム等による手入れをしなくなったこ

Table-1 Chapping value on lip condition during seasons and ages

\begin{tabular}{|c|c|c|c|c|c|c|c|c|c|}
\hline & & 季 & 節 & 変 & 化 & & 年 & 齢 & 差 \\
\hline & 9 月 & 11月 & 1 月 & 4 月 & 6 月 & 9 月 & 25以下 & $26 \sim 35$ & 35 以上 \\
\hline 荒れ評洒点 & 1.29 & 1.73 & 1.84 & 1.47 & 1.63 & 1.28 & 1.73 & 1.68 & 1.36 \\
\hline （標準偏差） & $(0.24)$ & $(0.55)$ & $(0.69)$ & $(0.46)$ & $(0.71)$ & $(0.30)$ & $(0.28)$ & $(0.45)$ & $(0.24)$ \\
\hline 有 意 差 & STD & ** & ** & - & $*$ & - & $* *$ & * & STD \\
\hline
\end{tabular}


と，冷房や柴外線圠る影響が推察されるが，原因は明 らかでない。

Fig.-3の荒れ評価点の分布状態からは，9月に比べ 冬には辟の状態の良い人が少なくなって扣り，荒机の程 度の悪い人が多くなることがわかる。
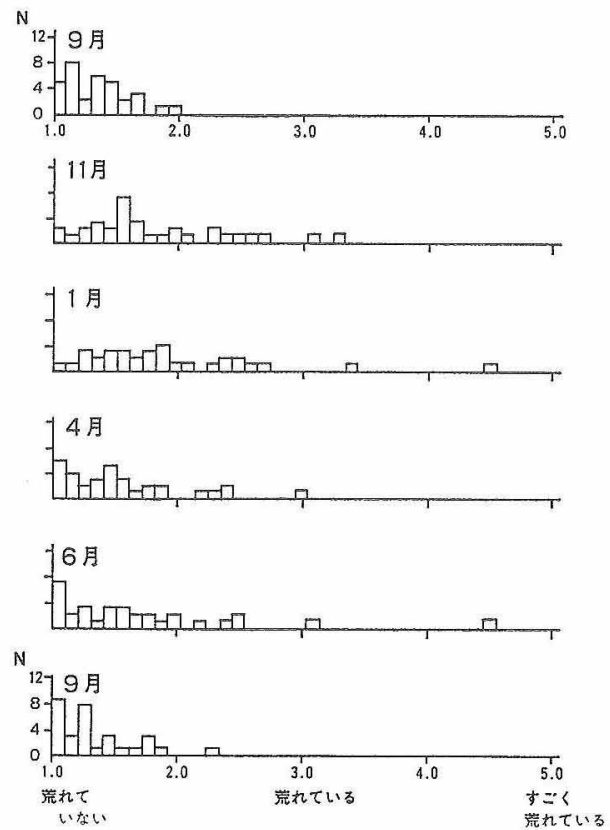

Fig.-3 Distribution of chapping value on lip condition

口唇の荒れの季節变化の例を Fig.-4, 5 に示す。

Fig.-4は6月に荒れがひどくなったケースであり（荒 れ評価点 4.4$) ， F i g － 5$ 月 1 月荒れた典型的な例で女る

(荒れ語洒点 4.4)。

また，冬場には縦じわ・深さが增し，綐じわ，横じわ の数も多くなることが観察された。

一方, 年笭差についてみると, 年間を通しての結果で 若い層の方が荒れやすい傾向が認められた。

\section{2 コンダクタンスの季節变化と年齡差}

インピーダンス測定による表皮水分量の結果をTable -2 に示す。11月，1月が 9 月と比較し，有意に低い結果 であった。しかし年齡差については，有意な差が認めら れなかった。

6 月のコンダクタンスが決して低くないことから，6 月の荒れは冬場の荒れの状況とは異なっていることが推 察される。

IP1 より IP2の方が顕著に差が出る傾向にあった。

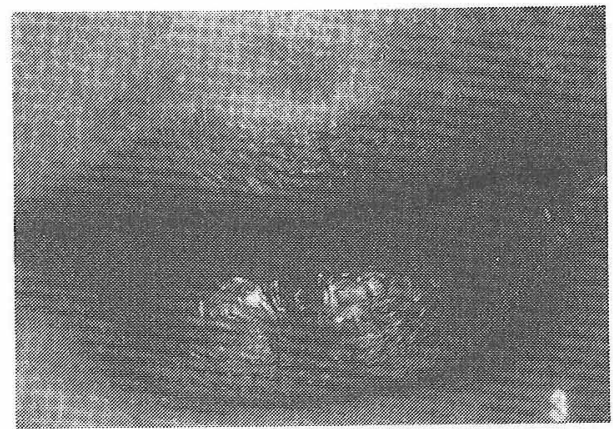

9 月

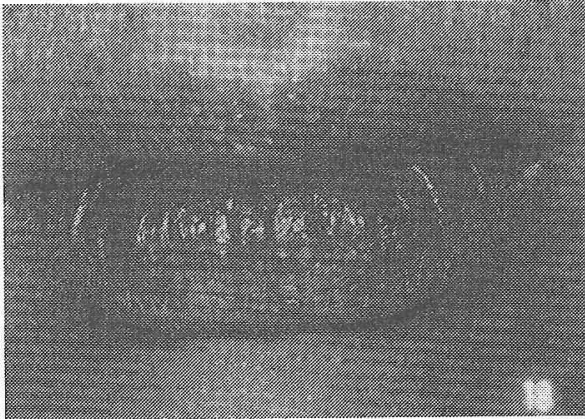

11月

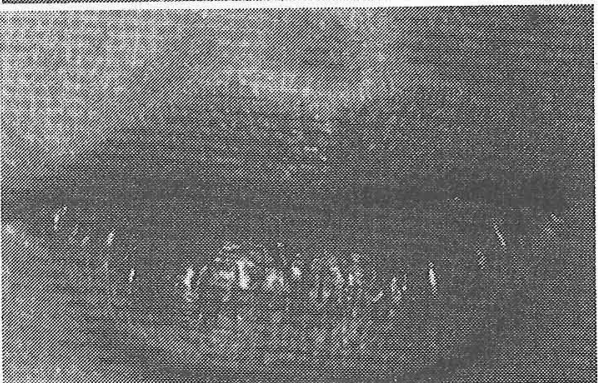

1 月

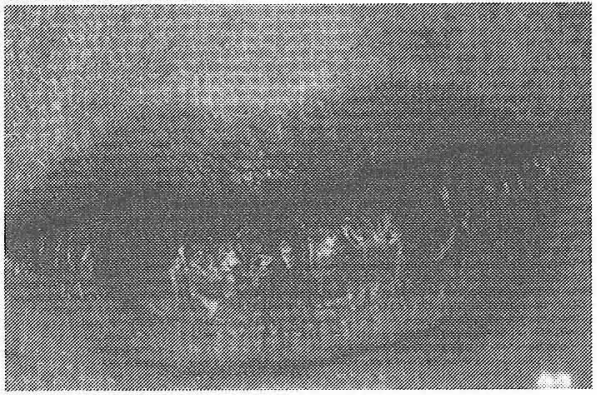

6 月

Fig.-4 Typical photograph of chap variation on lip condition (1)

Fig. -6 分布からb, 冬にはコンダクタンスの高い 人が少なくなっており，平均的な $15 \mu$ モーより低い人が 多くなっていることがわかる。

\section{3 季節間の相関性}

Table-3 に示した，荒れ評価点とIP それぞれの季節 


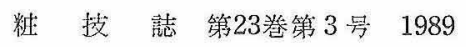

Table-2 Conductance on lip condition during seasons and ages

\begin{tabular}{|c|c|c|c|c|c|c|c|c|c|}
\hline & \multicolumn{2}{|r|}{ 李 } & 節 & 変 & \multicolumn{2}{|l|}{ 化 } & 年 & 噛 & 差 \\
\hline & 9 月 & 11月 & 1 月 & 4月 & 6 月 & 9 月 & 25以下 & $26 \sim 35$ & 35 以上 \\
\hline $\operatorname{IP} 1[\mu \leftleftarrows-]$ & 23.9 & 13.4 & 13.9 & 14.8 & 15.9 & 18.9 & 13.3 & 16.1 & 21.1 \\
\hline （標準偏美） & $(24.7)$ & $(9.2)$ & (13.7) & (11.8) & (16.5) & $(20.0)$ & $(11.5)$ & $(9.8)$ & $(12.0)$ \\
\hline 有 意 差 & STD & * & * & - & — & - & - & - & STD \\
\hline $\operatorname{IP} 2[\mu \leftleftarrows-]$ & 33.6 & 16.8 & 14.3 & 23.5 & 27.5 & 36.2 & 22.7 & 23.5 & 28.9 \\
\hline （標準偏差） & (31.9) & $(10.2)$ & $(13.5)$ & (25.1) & $(33.0)$ & $(40.1)$ & (11.8) & $(13.3)$ & (21.5) \\
\hline 有意羙 & $\mathrm{STD}$ & ** & $* *$ & - & - & 一 & - & - & STD \\
\hline
\end{tabular}

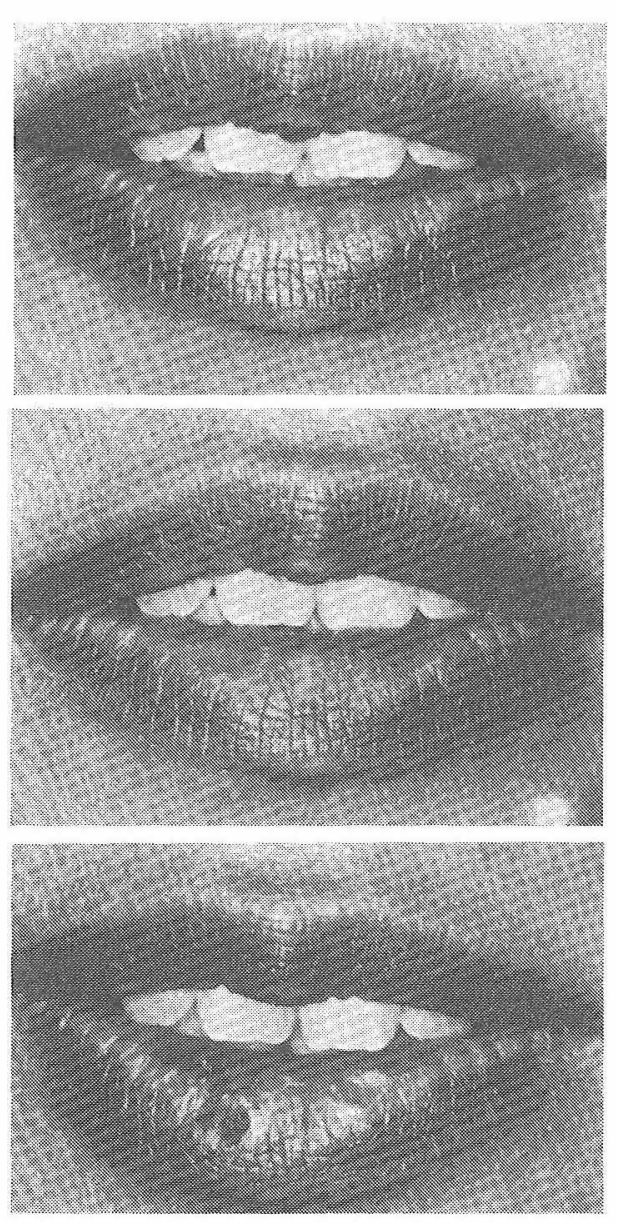

Fig. -5 Typical photograph of chap variation on lip condition ( 2 )

間の相関をみてみると，荒机評洒点については 1 月と他 の月との相関が弱く，1月に荒れを起こした人の中に他 の月ではあまり荒れていない，すなわb1月に特異的飞
Table-3 Correlations during seasons of chapping value and moisture content

\begin{tabular}{|c|c|c|c|c|c|c|c|c|}
\hline & & & \multicolumn{6}{|c|}{ インピーダンス值 } \\
\hline & & & 9 月 & 11月 & 1 月 & 4月 & 6 月 & 9 月 \\
\hline \multirow{6}{*}{$\begin{array}{l}\text { 荒 } \\
\text { れ } \\
\text { 評 } \\
\text { 洒 } \\
\text { 点 }\end{array}$} & 9 & 月 & & * & $* *$ & $* *$ & $* *$ & $* *$ \\
\hline & & 月 & $* *$ & & 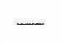 & $*$ & 一 & - \\
\hline & 1 & 月 & - & 一 & . & $一$ & - & 一 \\
\hline & 4 & 月 & $* *$ & $*$ & $\ldots$ & $-\infty$ & $*$ & - \\
\hline & 6 & 月 & $*$ & * & - & - & & *** \\
\hline & 9 & 月 & $* *$ & *** & - & $*$ & $* *$ & \\
\hline
\end{tabular}
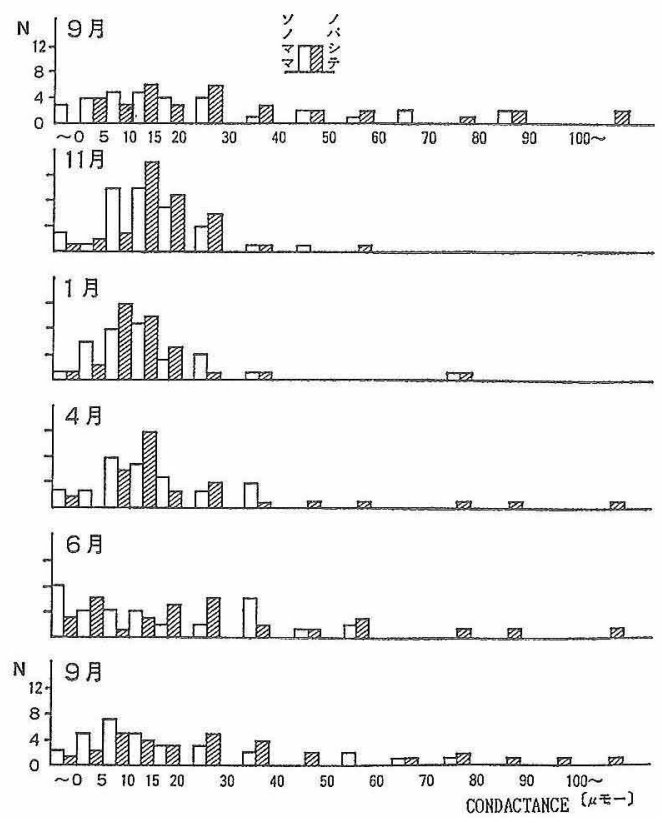

Fig.-6 Distribution of conductance on lip condition 
荒れた人が多かったためと考えられる。

表皮水分量測定の季節間の相関性については，1月と 11月が他の月との相関が弱く，この時期に特異的な動き があったことをらかがわせる結果だった。

\section{4 口長の色分布}

口唇の色については，季節間のはっさりした変化傾向 がつかめなかった。これには, 測定法の問題や他の要因 の影響が大きかったことが考えられる。

下唇のマンセル值の年間平均は, $7.16 \mathrm{R} \quad 6.17 / 3.95$ であった。口唇の色分布の結果を Fig.-7 に示す。

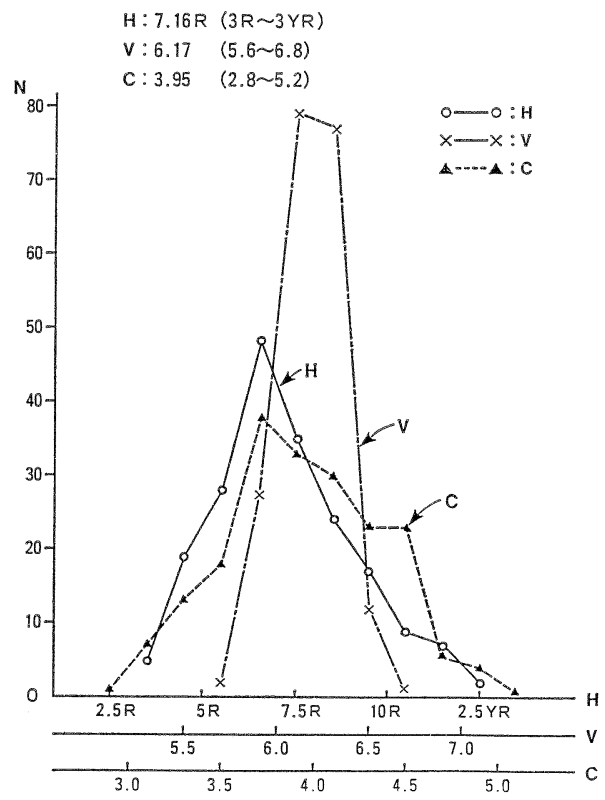

Fig. -7 Distribution of color on lip condition

\section{5 口唇の表面温度分布}

口唇の表面温度も平均でみると, はっきりした季節変 化が久られなかった。年間を通しての全体の平均值は， $34.56^{\circ} \mathrm{C}$ であり，31.7〜 $36.1^{\circ} \mathrm{C}$ に分布していた。（Fig. -8)

当初予想していた体温との相関は認められなかった。

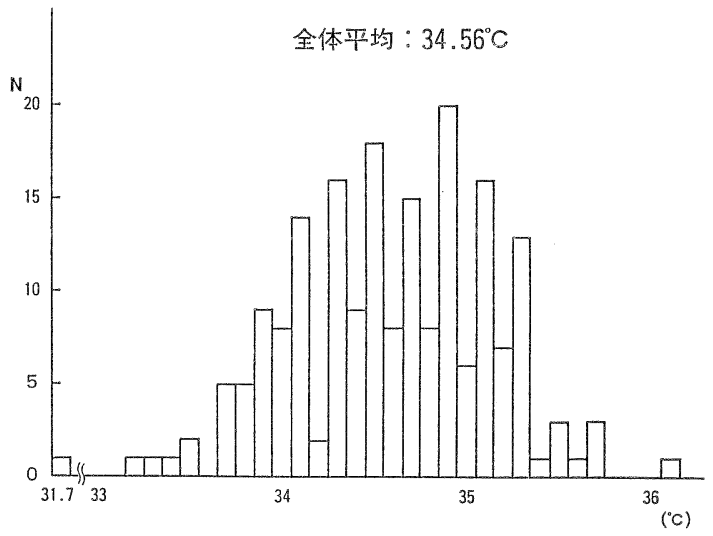

Fig.-8 Distribution of surface temperature on lip condition

\section{6 各項目間の相関性}

次に各測定項目間の相関について検討し，相関性の認 められた項目を Table-4 に整理した。

写真評価による荒れ評価点は，ささくれ，かいよう評 価点と相関が高く，この項目が荒れ評価の大きな要素に なっているといえる。また，自己診断結果や申告しても らった唇の荒れやすさとも相関しており， 口唇の荒れに 対与る写真評価法は，妥当性があるものと考光られる。

Table-4 Correlations during factors on lip condition

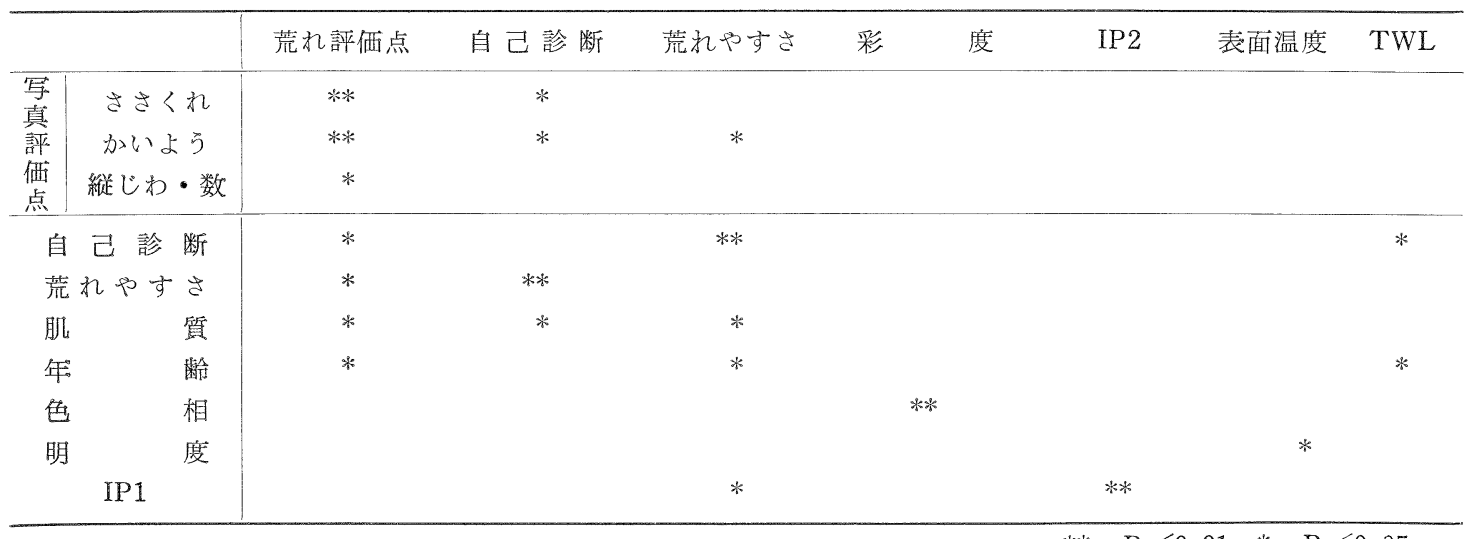


他の項目では，色相と彩度に逆相関の関係があった。 表面温度は明度と逆相関がみられた。IP1が荒れやすさ と, TWL が自己診断結果と相関し, 年齢とは逆相関が 認められたことも注目すべき点であった。

\section{7 口唇の荒れに影響する要因}

さらに以上の結果をもとに, 有意差が認められた季 節, 年柃以外の唇の荒れやすさに影響を及ぼす要因につ いて検討した。その結果, IP1 は荒れ評価点と直接相関 が認められなかったが，10 $\mu$ モー以下のグループについ てみると，それ以上のグループに比べ有意 $(\mathrm{P}<0.05)$ に荒れやすいことがわかった。

また, Fig.-9に示すよらに, TWLとの関係では, IP1 が高くTWL が低いグループが有意 $(\mathrm{P}<0.01)$ に荒れ にくいといら結果でめった。IP1 が平均以下の人達につ いて表面温度との関係をみると, 口唇の表面温度が平均 より低いグループが高いグループより，有意 $(\mathrm{P}<0.05)$ に荒れやすいこともわかった。

さらに, 縦じわ・数の少ないグループが有意 $(\mathrm{P}<$ 0.01）に荒れやすく, IP1 が高くても荒れやすいことが わかった。これは，縦じわの少ない人は表皮が薄い傾向

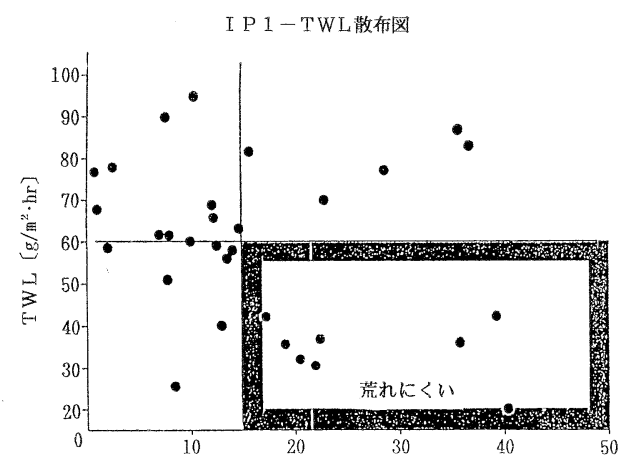

IP $1[\mu E-]$

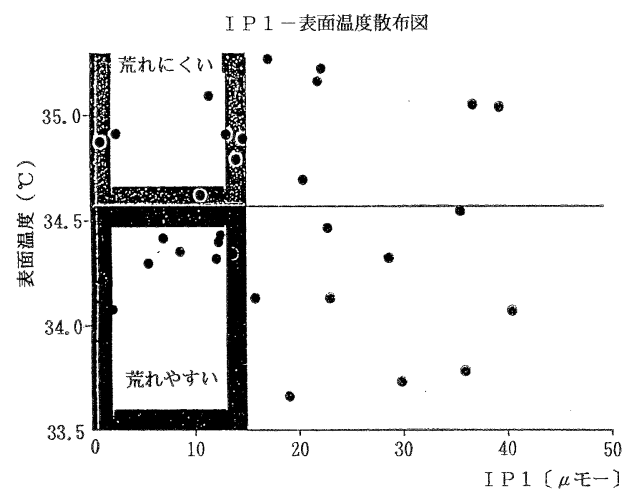

にあり，荒れやすくしていることが考光られる。 その他，肌質が敏感であると答えた人は，荒れ評価点 も高く荒れやすい傾向にあった。

\section{4. 総 括}

口唇の季節変化を把握するため, いくつかの評価法を 検討した結果，唇の荒れは特に冬期に起こりやすく，6 月頃子要注意の時期であること, 冬には表皮水分量が確 実に減少して拈り，乾燥がちになっていることもわかっ た。年間を通して荒れやすい人は，若い層に多かった。

口唇の荒れ予防, 改善方法としては, TWLを抑制し, 表皮水分量を増やすこと，すなわら適度な閉塞性を付与 し, 水分保持能をアップさせ，水分を補らような対応と 血行促進に配慮することが効果的と考兄られる。

口唇についても、人によりそれぞれ特徴があることか ら，今後唇に和いてもよりきめ細かな対応が必要と思わ れる。

今回実施した評価法は, 今後改良を加えていく必要が めるが，口唇表面状態についての各種の情報を得るため に，有効な方法として活用できるものと若える。

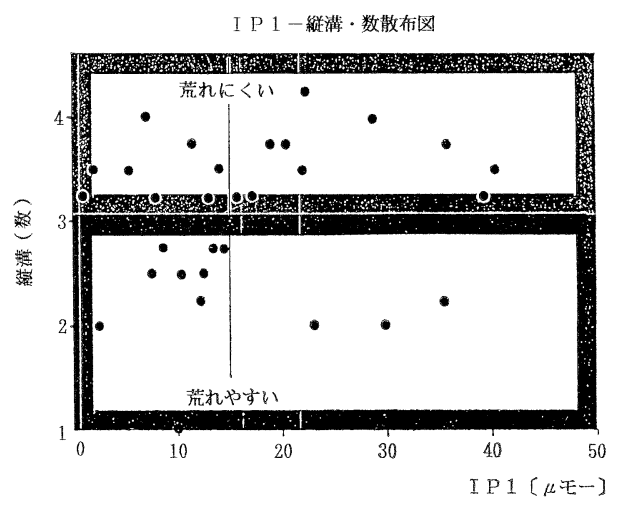

Fig.-9 Influence factors of chapping on lip condition 


\section{参考文献}

1）金子治, 舘和男, 花田千代美, 田中宗男,

J. Soc. Cosmet. Chem. Japan, 13, 7 (1979)
2）有馬八重野, 松永佳世子, 早川律子, 皮膚, 27 , 974 (1985)

（平成元年 2 月 17 日受理） 